PRÁVNE ROZPRAVY ON-SCREEN III. - Sekcia súkromného práva

online vedecká konferencia - 7. máj 2021

\title{
DISKREPANCIA POSUDKOVÝCH ZÁVEROV PODLA ZÁKONA O OCHRANE VEREJNÉHO ZDRAVIA A ZÁKONNÍKA PRÁCE ${ }^{1}$ \\ DISCREPANCY OF CONCLUSIONS OF MEDICAL STATEMENTS ACCORDING TO THE PUBLIC HEALTH PROTECTION ACT AND LABOUR CODE
}

Jana Žul'ová2 - Monika Minčičováa ${ }^{3}$

https://doi.org/10.24040/pros.07.05.2021.ssp.338-348

\begin{abstract}
Abstrakt
Lekársky posudok je právne relevantný doklad obsahujúci informáciu o zdravotnej (ne)spôsobilosti fyzickej osoby alebo zamestnanca na prácu. Lekárom určený záver má priamy dosah na d’alši priebeh pracovnoprávneho vzt’ahu. Vzhl'adom na závažnost' vyvolaných dôsledkov lekárskeho posudku pre dotknuté subjekty pracovnoprávneho vzt’ahu je dôležitá jednoznačnost' jeho záveru. Ciel’om príspevku je poukázat’ na nesúlad posudkových záverov predpokladaných zákonom o ochrane verejného zdravia a Zákonníkom práce na konkrétnych pracovnoprávnych situáciách a predstavit’ možný postup preklenutia tejto rozpornosti v právnom stave de lege lata a de lege ferenda.
\end{abstract}

\section{Kl’účové slová}

Lekársky posudok o zdravotnej spôsobilosti na prácu, posudkové závery, zákon o ochrane verejného zdravia, Zákonník práce.

\begin{abstract}
A medical statement is a legally relevant document containing information about the health (in) capacity of a person or employee for work. The conclusion determined by the doctor has a direct impact on the further continuance of the employment relationship. Given the seriousness of the consequences of a medical statement for the affected subjects of employment relationship, there is the importance of its unambiguously conclusion. The aim of the authors is to point out the inconsistency of the conclusions of medical statements assumed by the Public Health Protection Act and the Labour Code on specific employment situations and to present a possible procedure for bypassing this discrepancy in the status de lege lata and de lege ferenda.
\end{abstract}

\footnotetext{
${ }^{1}$ Príspevok bol spracovaný v rámci riešenia grantového projektu APVV-16-0002 Duševné zdravie na pracovisku a posudzovanie zdravotnej spôsobilosti zamestnanca.

2 JUDr. Jana Žul'ová, PhD., Univerzita Pavla Jozefa Šafárika v Košiciach, Právnická fakulta, katedra pracovného práva a práva sociálneho zabezpečenia, odborná asistentka.

3 JUDr. Monika Minčičová, PhD., Univerzita Pavla Jozefa Šafárika v Košiciach, Právnická fakulta, katedra pracovného práva a práva sociálneho zabezpečenia, vedecká pracovníčka.
} 


\section{PRÁVNE ROZPRAVY ON-SCREEN III. - Sekcia súkromného práva}

online vedecká konferencia - 7. máj 2021

\section{Keywords}

Medical statement of health capacity for work, conclusions of medical statements, Public Health Protection Act, Labour Code

\section{Úvod}

Zamestnávatel' nesmie pripustit', aby zamestnanec vykonával prácu, na ktorú nie je zdravotne spôsobilý. Podl'a ust. $§ 6$ ods. 1 písm. o) zákona č. 124/2006 Z. z. o bezpečnosti a ochrane zdravia pri práci a o zmene a doplnení niektorých zákonov (d’alej len zákon o BOZP), je zamestnávatel' povinný zarad'ovat' zamestnancov na výkon práce so zretelom na ich zdravotný stav, najmä na výsledok posúdenia ich zdravotnej spôsobilosti na prácu. Ani zamestnanec, ani zamestnávatel' však nie sú odborne spôsobilí, aby sami vyslovili záver, či je daná práca vzhl’adom na momentálny zdravotný stav zamestnanca vhodná a či ju môže vykonávat' bez následkov na jeho zdravie. Posudzovanie zdravotnej spôsobilosti na prácu je preto zverené lekárom. ${ }^{4}$ Tí v rámci lekárskej preventívnej prehliadky na základe medicínskeho zhodnotenia výsledkov stanovených vyšetrení majú prijat' právne aprobovaný záver o zdravotnej spôsobilosti, či nespôsobilosti posudzovanej osoby. Výsledkom posúdenia zdravotnej spôsobilosti na prácu je (má byt') lekársky posudok, ktorého náležitosti upravuje § 30f ods. 2 zákona č. 355/2007 Z. z. o ochrane, rozvoji a podpore verejného zdravia a o zmene a doplnení niektorých zákonov (d’alej len zákon o ochrane verejného zdravia) a vzory lekárskych posudkov o zdravotnej spôsobilosti na prácu upravuje príloha č. $3 c$ citovaného zákona. V aplikačnej praxi sa však neraz možno stretnút' s tým, že zamestnancom predložený lekársky posudok nevyvolá očakávané pracovnoprávne účinky a účastníci pracovnoprávneho vzt'ahu sa tak ocitajú v právnej neistote ohl’adne pokračovania v d’alšom výkone dohodnutej práce. Popísaný stav je dôsledkom interpretácie záveru predloženého lekárskeho posudku, ked’že tento nie je vždy formulačne kompatibilný s relevantnými ustanoveniami zákona č. 311/2001 Z. z. Zákonníka práce (d’alej ako Zákonník práce). Aj ked’ je lekársky posudok vydaný v súlade so zákonom o ochrane verejného zdravia, môže sa stat', že pre vyvolanie právnych účinkov podl'a Zákonníka práce to nebude stačit'. Predkladaný príspevok poukazuje na formulačné neprepojenie posudkových záverov upravených zákonom o ochrane verejného

\footnotetext{
${ }^{4}$ BARANCOVÁ, H.: Zákonník práce. Komentár. Bratislava: C. H. Beck, 2017, s. 214.
} 


\section{PRÁVNE ROZPRAVY ON-SCREEN III. - Sekcia súkromného práva}

online vedecká konferencia - 7. máj 2021

zdravia s príslušnými ustanoveniami Zákonníka práce ${ }^{5}$ a zamýšl’a sa nad možným riešením tejto diskrepancie v stave de lege lata.

\section{Závery lekárskych posudkov podl’a zákona o ochrane verejného zdravia v korelácii s ustanoveniami Zákonníka práce}

Lekársky posudok o zdravotnej spôsobilosti na prácu môže podl’a prílohy č. 3c zákona o ochrane verejného zdravia obsahovat' tri závery. Informáciu o tom, či je posudzovaná osoba:

i. spôsobilá na výkon posudzovanej práce,

ii. Spôsobilá na výkon posudzovanej práce s dočasným obmedzením alebo

iii. dlhodobo nespôsobilá na výkon posudzovanej práce. ${ }^{6}$

Záver o zdravotnej spôsobilosti na výkon posudzovanej práce nevzbudzuje žiadne výkladové problémy. Nájdeme niekol'ko ustanovení Zákonníka práce, ktoré predvídajú takto formulovaný záver a viažu na predloženie lekárskeho posudku s takýmto záverom pracovnoprávne účinky. Ako jeden príklad za všetky možno uviest' ust. § 41 ods. 2 Zákonníka práce, podl'a ktorého, ak osobitný právny predpis vyžaduje na výkon práce zdravotnú spôsobilost' na prácu,... zamestnávatel' môže uzatvorit' pracovnú zmluvu len s fyzickou osobou zdravotne spôsobilou na túto prácu. ${ }^{7}$

Na záver lekárskeho posudku o zdravotnej spôsobilosti na výkon posudzovanej práce s dočasným obmedzením explicitne neodkazuje žiadne ustanovenie Zákonníka práce. V tomto prípade ide vaplikačnej praxi o reálnu úpravu podmienok výkonu práce a pracovných

\footnotetext{
${ }^{5}$ To, že nejde len o problém slovenskej právnej úpravy, dokazuje aj česká odborná literatúra: TOMŠEJ, J.: Pracovnélékařské služby. 3. vyd. Praha: Wolters Kluwer, 2020, s. 80.

${ }^{6}$ Do prijatia zákona č. 289/2017 Z. z., na základe ktorého došlo k novelizácii zákona o ochrane verejného zdravia, boli závery lekárskych posudkov vydaných pracovnou zdravotnou službou variabilnejšie, a okrem aktuálnych záverov, mohol lekár konštatovat’ i to, že fyzická osoba/zamestnanec je spôsobilý na výkon práce s trvalým obmedzením a dočasne nespôsobilý na výkon práce. Na základe požiadaviek praxe boli tieto zo zákona vypustené.

${ }^{7}$ Z gramatického znenia Zákonníka práce síce $\mathrm{v}$ tomto prípade (i v niektorých d’alších) nevyplýva explicitná požiadavka predloženia lekárskeho posudku, napriek tomu preukázanie zdravotnej (ne)spôsobilosti týmto formálnym dokladom môžeme odvodit’ z predpisov na ochranu zdravia (§ 16 zákona č. 576/2004 Z. z. o zdravotnej starostlivosti, službách súvisiacich s poskytovaním zdravotnej starostlivosti a o zmene a doplnení niektorých zákonov a zákona o ochrane verejného zdravia), ktoré vydanie lekárskeho posudku, ako doviršenie procesu posúdenia zdravotnej spôsobilosti na prácu, predpokladajú.
} 


\section{PRÁVNE ROZPRAVY ON-SCREEN III. - Sekcia súkromného práva}

online vedecká konferencia - 7. máj 2021

podmienok tak, aby mohla byt' práca d'alej vykonávaná bez ohrozenia zdravia zamestnanca. ${ }^{8}$ Súčast'ou tohto posudkového záveru tak má byt' aj konkretizácia obmedzení vzt'ahujúca sa k výkonu posudzovanej práce. Má íst’ o obmedzenia trvajúce dočasne, ako napríklad to, že posudzovaná osoba nebude určitý čas pracovat' vo výškach, v hlučnom, prašnom prostredí, v noci, dočasne ručne manipulovat' s bremenami, dôjde k skráteniu jej pracovného času alebo bude pri výkone práce určitý čas potrebovat' kompenzačnú alebo zdravotnícku pomôcku. Formulácia a vyjadrenie týchto obmedzení je kl’účové a je treba pritom vziat' do úvahy konkrétne pracovné zradenie posudzovanej osoby, u konkrétneho zamestnávatel'a, pri danej technológií, organizácii práce, či d’alších požiadaviek nevyhnutných pre riadny výkon danej práce. ${ }^{9}$ Z praktického hl'adiska je vel'mi podstatné, aby v lekárskom posudku uvedené dočasné obmedzenie bolo u daného zamestnávatel’a reálne možné a vykonatel'né. Sledovanie tejto skutočnosti však lekárovi žiadna právna norma nepredpisuje. Lekársky posudok s nesplnitel’ným dočasným obmedzením dostáva zamestnávatel’a do patovej situácie. $\mathrm{Na}$ jednej strane nemôže zamestnancovi dovolit' vykonávat' prácu, ktorá by ohrozila jeho zdravie, na druhej strane nevie zamestnanca ani preradit' na výkon inej práce, ani dat' zamestnancovi výpoved', pretože tieto možnosti sa spájajú so záverom o dlhodobej nespôsobilosti na výkon posudzovanej práce (k tomu pozri d’alej). Možná je len dohoda o zmene pracovnej zmluvy (napr. o dočasnom zúžení dohodnutého druhu práce) a v prípade, že zamestnanec nebude so zmenou súhlasit', vzniká na strane zamestnávatel'a tzv. iná prekážka podl’a $§ 142$ ods. 3 Zákonníka práce.

Pokial' ide o lekársky posudok so záverom o dlhodobej zdravotnej nespôsobilosti, predloženie takéhoto posudku vyvoláva niekol'ko explicitne vyjadrených pracovnoprávnych dôsledkov. Podl'a ust. § 55 ods. 2 písm. a) Zákonníka práce je zamestnávatel' povinný preradit' zamestnanca na inú prácu, ak zamestnanec vzhl’adom na svoj zdravotný stav podl'a lekárskeho posudku dlhodobo stratil spôsobilost' nad'alej vykonávat' doterajšiu prácu. Podl'a ust. § 63 ods. 1 písm. c) Zákonníka práce zamestnávatel' môže so zamestnancom skončit' pracovný pomer výpoved'ou, ak zamestnanec vzhl'adom na svoj zdravotný stav podla lekárskeho posudku dlhodobo stratil spôsobilost' vykonávat' doterajšiu prácu a s uvedeným spôsobom skončenia pracovného pomeru je tiež spojená povinnost' vyplatit' odstupné podl'a $\S$ 76 ods. 2 Zákonníka práce. V týchto situáciách je podkladom pre konanie zamestnávatel’a,

\footnotetext{
8 ŠVEC, M. - OLŠOVSKÁ, A.: Zdravotný stav zamestnanca v pracovnom práve. In: Právo a manažment $\mathrm{v}$ zdravotníctve, č. 2, 2014.

9 ŠUBRT, B. - TUČEK, M.: Pracovnělékařské služby. Povinnosti zaměstnavatelů a lékařu. Praha: Nakladatelství ANAG, 2019, s. 221.
} 


\section{PRÁVNE ROZPRAVY ON-SCREEN III. - Sekcia súkromného práva}

online vedecká konferencia - 7. máj 2021

resp. nárok zamestnanca lekársky posudok so záverom o dlhodobej nespôsobilosti na výkon posudzovanej práce. Problémom je, že žiadne zákonné ustanovenie nešpecifikuje, ako dlho má trvat' zdravotná nespôsobilost' posudzovanej osoby, aby ju bolo možné považovat' za dlhodobú. ${ }^{10}$ Dlhodobá nespôsobilost' by mala evokovat' celkovú zdravotnú nespôsobilost' na výkon posudzovanej práce. Určenie, že zdravotný stav zamestnanca z dlhodobého hl'adiska nedovol’uje výkon konkrétnej práce potom zostáva výlučne v kompetencii lekára. Choroba, ochorenie, stav, ktoré posudzovanej osobe momentálne (dočasne) bránia vo výkone práce (zlomeniny, vírusové ochorenie, tehotenstvo), by nemali viest' automaticky káveru o zdravotnej nespôsobilosti, a teda je nevyhnutné od dlhodobej zdravotnej nespôsobilosti odlišovat' dočasnú pracovnú neschopnost'. ${ }^{11}$ Samozrejme, nemožno vylúčit' ani situácie, ak choroba, v dôsledku ktorej sa zamestnanec stane dočasne práceneschopný, vyústi pri hodnotení zdravotného stavu po návrate do práce do záveru o dočasnej alebo dlhodobej zdravotnej nespôsobilosti na prácu.

\section{Ustanovenia Zákonníka práce v (ne)súlade so závermi lekárskych posudkov podl’a zákona o ochrane verejného zdravia}

Zákonník práce má „,vlastné predstavy“ o tom, ako by mali byt’ formulované niektoré závery zhodnocujúce zdravotnú spôsobilost' zamestnanca na výkon posudzovanej práce. Povinnost' preradenia na inú prácu podl’a $§ 55$ ods. 2 písm. b) Zákonníka práce vzniká zamestnávatel'ovi vtedy, ak tehotná žena, matka do konca deviateho mesiaca po pôrode a dojčiaca žena vykonáva prácu ..., ktorá podl'a lekárskeho posudku ohrozuje jej tehotenstvo alebo materské poslanie. Takýto konkrétny posudkový záver zákon o ochrane verejného zdravia nepredvída. Výkladom je možné dospiet' k záveru o použitel’nosti záveru spôsobilá na výkon posudzovanej práce s dočasným obmedzením. Tehotenstvo, materstvo, dojčenie nesmú byt' dôvodom, pre ktorý by bola v lekárskom posudku konštatovaná dlhodobá zdravotná nespôsobilost' na výkon posudzovanej práce, pretože takýto posudok oprávňuje zamestnávatel'a ku skončeniu pracovného pomeru výpoved’ou podl’a $\S 63$ ods. 1 písm. c) Zákonníka práce. Domnievame sa, že posudkový záver o spôsobilosti s dočasným

\footnotetext{
${ }^{10}$ Na rozdiel od Českej republiky. Podl’a § 44 ods. 4 zákona č. 373/2011 Sb. o špecifických zdravotných službách ide o stav trvajúci viac než 180 dní.

${ }^{11}$ LACKO, M.: Dočasná pracovná neschopnost' zamestnanca. 1. vyd. Praha: Leges, 2019. s. 23.
} 


\section{PRÁVNE ROZPRAVY ON-SCREEN III. - Sekcia súkromného práva}

online vedecká konferencia - 7. máj 2021

obmedzením by mal byt' využitý aj v prípade posudku zo vstupnej lekárskej preventívnej prehliadky, ak sa o pracovnú pozíciu zakázanú (či už všeobecne právnym predpisom, alebo individuálne na základe lekárskeho posudku) tehotným ženám, matkám do konca deviateho mesiaca po pôrode alebo dojčiacim ženám uchádza takáto uchádzačka o zamestnanie. Vo všetkých prípadoch ide o nespôsobilost' na výkon posudzovanej práce trvajúcu len určitú, obmedzenú dobu.

Povinnost' preradenia na inú prácu podl’a $§ 55$ ods. 2 písm. e) Zákonníka práce vzniká zamestnávatel'ovi tiež vtedy, ak zamestnanec pracujúci v noci na základe lekárskeho posudku je uznaný za nespôsobilého na nočnú prácu. ${ }^{12}$ Ani takýto posudkový záver, zákon o ochrane verejného zdravia neuvádza. Nespôsobilost' na nočnú prácu môže mat' dočasný, ale aj dlhodobý charakter, pričom v oboch prípadoch vzniká zamestnávatel'ovi povinnost' preradit' zamestnanca na inú vhodnú prácu. Zamestnanec stále môže vykonávat' dohodnutú prácu, nie však v noci. Posudzujúci lekár pre tento účel môže konštatovat' spôsobilost' na výkon posudzovanej práce s dočasným obmedzením. Záver zaväzuje zamestnávatel'a, aby pracovné podmienky zamestnanca upravil tak, aby mohol prácu vykonávat' len počas dňa (v čase od 6:00 do 22:00 hodiny). Z posudkového záveru by malo vyplývat' aj časové ohraničenie nespôsobilosti na výkon nočnej práce. Dočasná nespôsobilost’ na výkon nočnej práce tiež chráni zamestnanca pred výpoved’ou zo strany zamestnávatel'a podl’a § 64 ods. 1 písm. f) Zákonníka práce. ${ }^{13} \mathrm{Ak}$ by nespôsobilost’ zamestnanca na nočnú prácu bola trvalá alebo neurčitel'ná, má byt' lekárskym posudkom konštatovaná dlhodobá nespôsobilost' na výkon posudzovanej (nočnej) práce. Rovnako by mal byt' tento posudkový záver o dlhodobej zdravotnej nespôsobilosti použitý aj vtedy, ak je nočná práca integrálnou súčast'ou výkonu práce $\mathrm{v}$ danej prevádzke, t. j. dohodnutá práca nemôže byt' vôbec vykonávaná bez práce v noci (napr. nočný strážnik). ${ }^{14}$

Uzatvorenie pracovnej zmluvy so žiakom (absolventom) strednej odbornej školy alebo odborného učilišt'a (d’alej len „SOŠ/OU“) môže zamestnávatel' odmietnut' pre zdravotnú nespôsobilost’ na výkon takej práce, pre ktorú žiak (absolvent) získal kvalifikáciu (§ 53 ods. 1 Zákonníka práce). Ďalší Zákonníkom práce predpokladaný posudkový záver vyplýva

\footnotetext{
${ }^{12}$ Bližšie: TOMAN, J. - ŠVEC, M. - RAK, P.: Pracovné právo v súvislostiach 1. vyd. Bratislava: Friedrich Ebert Stiftung, 2020. s. 128.

${ }_{13}$ Bližšie pozri: PETRÍKOVÁ, L.: Vplyv nočnej práce na život a zdravie zamestnanca. In: Zdravotná spôsobilost' zamestnancov: recenzovaný zborník príspevkov z vedeckej konferencie. Košice, 15. až 25. mája 2020. 1. vyd. - Košice : Univerzita Pavla Jozefa Šafárika v Košiciach: Univerzita Pavla Jozefa Šafárika, 2020, s. 216-226.

${ }^{14}$ BUKOVJAN, P.: Výkladová stanoviska AKV. Praha: Wolters Kluwer, 2015, s. 88.
} 


\section{PRÁVNE ROZPRAVY ON-SCREEN III. - Sekcia súkromného práva}

online vedecká konferencia - 7. máj 2021

z osobitných podmienok pri zamestnávaní mladistvých zamestnancov. V praxi pôjde zväčša o nadväznost' na predtým uzatvorenú zmluvu o budúcej pracovnej zmluve so žiakom SOŠ/OU podl'a § 53 Zákonníka práce, ked’že zamestnávatel' $\mathrm{v}$ iných prípadoch nie je povinný zamestnávat' mladistvých iba na prácu, ktorá zodpovedá ich kvalifikácii. Zamestnávatel' je povinný mladistvému pridel'ovat' inú primeranú prácu, ak doterajšia práca podl'a lekárskeho posudku ohrozuje jeho zdravie (§ 174 ods. 3 Zákonníka práce). Súhlasíme s názorom M. Barinkovej, že „pomocou výkladových metód v práve možno dôjst' k záveru, že ak konkrétna práca ohrozuje zdravie, nie je vhodné a s ohl'adom na ochranu zdravia ani žiaduce, aby ju osoba vykonávala. Domnievame sa, že tento stav nemusí byt' nemenný a že jej zdravotný stav sa môže zlepšit' (ale i zhoršit'). S možnost'ou zlepšenia zdravotného stavu počíta i Zákonník práce zakotvujúc povinnost' zamestnávatel'a poskytnút' zamestnancovi inú prácu zodpovedajúcu pokial' možno kvalifikácii až dovtedy, kým prácu, na ktorú získal kvalifikáciu, bude môct' vykonávat'. Máme za to, že v danom prípade, s ohl’adom na okolnosti prípadu, by lekársky posudok mal v závere obsahovat' výrok o zdravotnej nespôsobilosti na posudzovanú prácu s dočasným obmedzením.“"15

Napokon, zamestnanec má možnost' okamžite skončit' pracovný pomer, ak podl'a lekárskeho posudku nemôže d'alej vykonávat' prácu bez vážneho ohrozenia svojho zdravia a zamestnávatel' ho nepreradil do 15 dní odo dňa predloženia tohto posudku na inú pre neho vhodnú prácu (§ 69 ods. 1 písm. a) Zákonníka práce). Z citovaného ustanovenia vyplýva, že zamestnanec môže pracovný pomer okamžite skončit', ak podl’a lekárskeho posudku nemôže d’alej vykonávat' prácu bez vážneho ohrozenia svojho zdravia. Predloženie lekárskeho posudku so záverom o dlhodobej nespôsobilosti na výkon práce je podl’a rozhodovacej činnosti súdov nepostačujúce. ${ }^{16}$ Súčast'ou lekárskeho posudku musí byt' aj vyjadrenie, že zamestnanec nemôže d'alej prácu vykonávat' bez vážneho ohrozenia svojho zdravia. ${ }^{17}$ Ak by zamestnanec predložil „iba“ lekársky posudok o dlhodobej nespôsobilosti k výkonu práce, z hl'adiska požiadavky $\S 69$ ods. 1 písm. a) Zákonníka práce by tento zamestnanec musel pristúpit' k žiadosti o d’alší posudok (alebo o doplnenie formulácie existujúceho posudku),

\footnotetext{
15 BARINKOVÁ, M.: Zdravotná spôsobilost’ žiakov na prácu v rámci prípravy na povolanie. In Zdravotná spôsobilost' zamestnancov: recenzovaný zborník príspevkov z vedeckej konferencie. Košice: Univerzita Pavla Jozefa Šafárika v Košiciach, 2020, s. 9-20.

16 Z judikatúry: rozsudok Najvyššieho súdu SR, sp. zn 3 Cdo 150/2005 z 27. 10. 2005, obdobne rozsudok Krajského súdu v Trnave, sp. zn. 23 CoPr/1/2019 z 5. 8. 2019.

${ }^{17}$ OLŠOVSKÁ, A. - DIVÉKYOVÁ, K. - MÉSZÁROS, M.: Okamžité skončenie pracovného pomeru. Praha: Wolters Kluwer ČR, 2019, s. 81. Porovnaj: DOLOBÁČ, M.: Posudzovanie zdravotnej spôsobilosti pri skončení pracovného pomeru. In: Súkromné právo: recenzovaný časopis zameraný na otázky aplikačnej praxe. Roč. 6, č. 5/2020, s. 188.
} 


\section{PRÁVNE ROZPRAVY ON-SCREEN III. - Sekcia súkromného práva}

online vedecká konferencia - 7. máj 2021

ktorý by okrem uvedeného konštatovania obsahoval aj vyjadrenie o nemožnosti výkonu práce bez vážneho ohrozenia svojho zdravia.

\section{Riešenie diskrepancie $v$ stave de lege lata}

Preukázali sme, že normatívne zakotvené závery lekárskych posudkov v prílohe č. 3c zákona o ochrane verejného zdravia nie sú vo vzájomnom formulačnom súlade s ustanoveniami Zákonníka práce. Je otázne, ako sa s týmto problémom majú vysporiadat' zúčastnené strany - posudzujúci lekár, zamestnanec i zamestnávatel'.

Posudzujúci lekár pri vydávaní lekárskeho posudku má formulovat' také závery, ako mu diktuje zákon o ochrane verejného zdravia. Na požiadavku osobitného zákona, t. j. Zákonníka práce na špecificky formulovaný záver lekárskeho posudku podl’a nášho názoru vôbec nemusí prihliadat', v mnohých prípadoch nemá o takejto požiadavke ani vedomost'. Ak ho uvedomelý zamestnanec požiada, aby do lekárskeho posudku doplnil textáciu z príslušného ustanovenia Zákonníka práce, posudzujúci lekár môže argumentovat', že príloha č. 3c zákona o ochrane verejného zdravia je pre neho záväzná a tá, okrem troch posudkových záverov (vid’ prvá čast' príspevku) žiadne iné formulácie nepredvída. Na druhej strane, nám nie je známa žiadna sankcia, ktorá by hrozila posudzujúcemu lekárovi, ak by niektorý z posudkových záverov podl'a zákona o ochrane verejného zdravia špecifikoval a doplnil o znenie príslušného ustanovenia Zákonníka práce formulujúceho zhodnotenie zdravotnej spôsobilosti zamestnanca vlastným spôsobom.

Pravdepodobne najt’ažšiu pozíciu má v tomto smere zamestnávatel'. Je to práve on, ktorý musí ustát' a obhájit' pridel'ovanie len takej práce zamestnancovi, na ktorú je zdravotne spôsobilý a plnit' si povinnosti, ktoré mu Zákonník práce ukladá (napr. pristúpit’ k preradeniu na inú prácu). Nie je prípustné, aby laxne konštatoval, že pokial' lekársky posudok neobsahuje v závere takú textáciu, akú požaduje Zákonník práce, neprizná lekárskemu posudku žiadne pracovnoprávne účinky. V zmysle rozhodnutia Najvyššieho súdu ČR, ak postupoval lekár podl'a vzoru lekárskeho posudku, ktorý v rozpore so zákonom s určitým posudkovým záverom nepočíta, nemôže byt' tento nedostatok na ujmu práv zamestnanca a túto obsahovú vadu posudku, je potrebné odstránit' výkladom. ${ }^{18}$ Ak teda v stave de lege lata predloží zamestnanec

\footnotetext{
${ }^{18}$ Rozsudok Najvyššieho súdu ČR, sp. zn. 21 Cdo 4142/2011 z 11. 6. 2012.
} 


\section{PRÁVNE ROZPRAVY ON-SCREEN III. - Sekcia súkromného práva}

online vedecká konferencia - 7. máj 2021

napríklad lekársky posudok o dlhodobej nespôsobilosti na výkon práce, na základe ktorého má zamestnávatel' preradit' zamestnanca na inú vhodnú prácu, ale neurobí tak do 15 dní od predloženia tohto posudku, zamestnanec je podl'a nášho názoru oprávnený platne okamžite skončit' pracovný pomer podl'a $§ 69$ ods. 1 písm. a) Zákonníka práce. Ak dôvetok posudku výkon d’alšej práce by vážne ohrozil zdravie zamestnanca absentuje, nemá tento nedostatok viest' $\mathrm{k}$ formalizovanému vysloveniu neplatnosti okamžitého skončenia pracovného pomeru zo strany zamestnanca. Ak sa zamyslíme nad tým, čo vyjadruje posudkový záver o dlhodobej zdravotnej nespôsobilosti, možno podl'a nášho názoru dospiet' $\mathrm{k}$ tomu, že v sebe subsumuje aj tú skutočnost', že d’alší výkon práce pre zamestnanca jednoducho nie je možný, pretože táto práca vážne ohrozuje jeho zdravie. Nevidíme dôvod, pre ktorý by mal zamestnanec pristupovat' k žiadosti o d'alší lekársky posudok alebo jeho doplnenie. Na druhej strane treba povedat', že aj zamestnávatel' pocit'uje potrebu právnej istoty, čomu nanútený výklad posudkových záverov nesvedčí. Jedinou možnost'ou zamestnávatel’a je však iba iniciovanie neformálneho podnetu k vydaniu nového lekárskeho posudku v rovnakej veci, čím sa opät' dostávame k otázke doplnenia lekárskeho posudku na žiadost' zamestnanca, ktorej lekár môže, ale nemusí vyhoviet'.

Nad rámec obsahového zamerania tohto príspevku krátko dopíňame, že uvedená diskrepancia môže viest' aj k d’alšiemu neželanému následku. Dotknuté subjekty sa často (mylne) domnievajú, že aj ked' prvotný lekársky posudok vydal napríklad lekár pracovnej zdravotnej služby v znení záverov podl’a zákona o ochrane verejného zdravia, posudok podl’a požiadavky Zákonníka práce môže následne vydat' akýkol'vek iný lekár podl’a zákona č. 576/2004 Z. z. o zdravotnej starostlivosti, službách súvisiacich s poskytovaním zdravotnej starostlivosti a o zmene a doplnení niektorých zákonov, ked’že vychádzajú z toho, že tento predpis posudkové závery neobsahuje a lekár nimi nie je limitovaný. Uvedené následne otvára praktický problém vydávania viacerých lekárskych posudkov od viacerých lekárov pre jeden pracovnoprávny účel.

\section{Záver}

Záver lekárskeho posudku je jeho najdôležitejšou čast'ou. Od záveru sa odvíjajú d'alšie možnosti konania účastníkov pracovnoprávnych vzt’ahov. Zamestnávatel' má povinnost' riadit' 


\section{PRÁVNE ROZPRAVY ON-SCREEN III. - Sekcia súkromného práva}

online vedecká konferencia - 7. máj 2021

sa záverom lekárskeho posudku a nesmie pripustit', aby zamestnanec vykonával prácu, na ktorú nie je zdravotne spôsobilý. Posudzujúci lekári pri formulovaní záverov nevychádzajú z pracovnoprávnej úpravy, na čo v konečnom dôsledku podl'a nášho názoru ani nie je dôvod. V praxi je tak nevyhnutné závery lekárskych posudkov uspôsobovat' na príslušné ustanovenia Zákonníka práce, čo vedie k právnej neistote subjektov pracovnoprávnych vzt'ahov. Ak zákon o ochrane verejného zdravia nepočíta s takými posudkovými závermi, ako by si „želal“ Zákonník práce, nemôže byt' táto skutočnost' zamestnancovi na ujmu, pretože inak dochádza k porušovaniu právnej istoty adresáta právneho vzt’ahu. Je teraz otázkou „kto z koho“. Teda, či by sa mali do zákona o ochrane verejného zdravia doplnit’ posudkové závery kompatibilné s tými, ktoré požaduje Zákonník práce, alebo práve naopak. Prikláňame sa skôr k záveru, že zmena by sa mala udiat' v Zákonníku práce, pretože formulácie posudkových záverov, tak ako sú vyjadrené v zákone o ochrane verejného zdravia sú univerzálnejšie. Navyše posudzovanie zdravotnej spôsobilosti na prácu je špecifickou otázkou neriešenou Zákonníkom práce. Ak Zákonník práce zveruje úpravu tejto otázky osobitnému právnemu predpisu, domnievame sa, že by to mal byt' Zákonník práce, ktoré svoje posudkové závery zosúladí s osobitnou (špecifickou) normou.

\section{ZOZNAM BIBLIOGRAFICKÝCH ODKAZOV}

1. BARANCOVÁ, H.: Zákonník práce. Komentár. Bratislava: C. H. Beck, 2017, 1520 s. ISBN 978-80-89603-78-7.

2. BARINKOVÁ, M.: Zdravotná spôsobilost' žiakov na prácu v rámci prípravy na povolanie. In: Zdravotná spôsobilost' zamestnancov: recenzovaný zborník príspevkov z vedeckej konferencie. Košice: Univerzita Pavla Jozefa Šafárika v Košiciach, 2020, s. 920. ISBN 978-80-8152-891-0.

3. BUKOVJAN, P.: Výkladová stanoviska AKV. Praha: Wolters Kluwer, 2015, 213 s. ISBN 978-80-7478-825-3.

4. DOLOBÁČ, M.: Posudzovanie zdravotnej spôsobilosti pri skončení pracovného pomeru. In: Súkromné právo: recenzovaný časopis zameraný na otázky aplikačnej praxe. Roč. 6, č. 5/2020, s. 185-189. ISSN. 1339-8652. 
PRÁVNE ROZPRAVY ON-SCREEN III. - Sekcia súkromného práva

online vedecká konferencia - 7. máj 2021

5. LACKO, M.: Dočasná pracovná neschopnost’ zamestnanca. 1. vyd. Praha: Leges, 2019. 110 s. ISBN 978-80-7502-366-7.

6. OLŠOVSKÁ, A. - DIVÉKYOVÁ, K. - MÉSZÁROS, M.: Okamžité skončenie pracovného pomeru. Praha: Wolters Kluwer ČR, 2019, 104 s. ISBN 978-80-7598-668-9.

7. PETRÍKOVÁ, L.: Vplyv nočnej práce na život a zdravie zamestnanca. In: Zdravotná spôsobilost' zamestnancov: recenzovaný zborník príspevkov z vedeckej konferencie. Košice, 15. až 25. mája 2020. 1. vyd. - Košice : Univerzita Pavla Jozefa Šafárika v Košiciach: Univerzita Pavla Jozefa Šafárika, 2020. ISBN 978-80-8152-891-0, s. 216-226.

8. ŠUBRT, B. - TUČEK, M.: Pracovnělékařské služby. Povinnosti zaměstnavatelì a lékařro. Praha: Nakladatelství ANAG, 2019, 447 s. ISBN 978-80-7554-233-5.

9. ŠVEC, M. - OLŠOVSKÁ, A.: Zdravotný stav zamestnanca v pracovnom práve. In: Právo a manažment $v$ zdravotníctve, č. 2, 2014. ISSN 1338-2071.

10. TOMAN, J. - ŠVEC, M. - RAK, P.: Pracovné právo v súvislostiach. 1. vyd. Bratislava: Friedrich Ebert Stiftung, 2020. 218 s. ISBN 978-80-89149-90-2.

11. TOMŠEJ, J.: Pracovnělékařské služby. 3. vyd. Praha: Wolters Kluwer, 2020, s. 80. 164 s. ISBN 978-80-7598-646-7.

12. Rozsudok Najvyššieho súdu SR, sp. zn 3 Cdo 150/2005 z 27. 10. 2005.

13. Rozsudok Krajského súdu v Trnave, sp. zn. 23 CoPr/1/2019 z 5. 8. 2019.

14. Rozsudok Najvyššieho súdu ČR, sp. zn. 21 Cdo 4142/2011 z 11. 6. 2012.

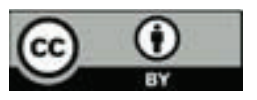

Obsah článku podlieha licencii Creative Commons Attribution 4.0 International Licence CC BY (Jana Žul'ová - Monika Minčičová). 